DEPÓSITO LEGAL ZU2020000153

Esta publicación científica en formato digital

es continuidad de la revista impresa

ISSN 0041-8811

E-ISSN 2665-0428

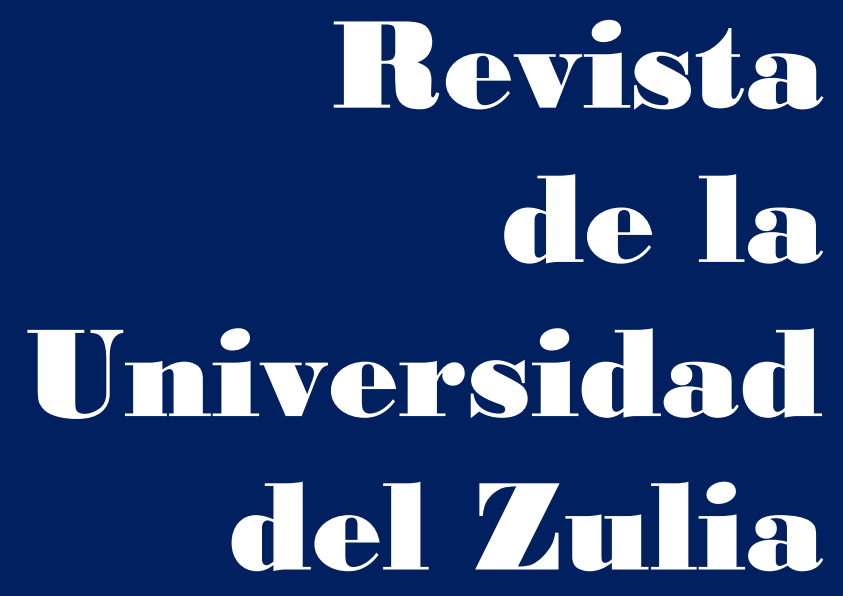

Fundada en 1947

por el Dr. Jesús Emrique Lossada

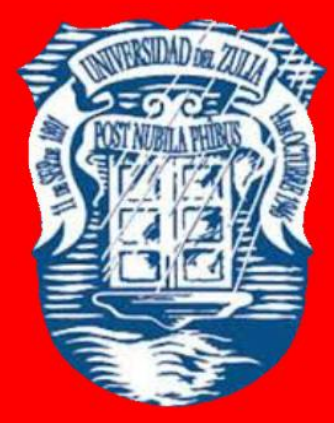

Ciencias

Sociales

y Arte

Año $12 \quad N^{\circ} 34$

Septiembre - Diciembre 2021

Tercera Época

Maracaibo-Veneruela 
REVISTA DE LA UNIVERSIDAD DEL ZULIA. 3a época. Año $12 \mathrm{~N}^{\circ} 34,2021$ Viktoriia Holubieva et al. /// Public procurement in Ukraine in the context of international ... 106-132 DOI: http://dx.doi.org/10.46925//rdluz.34.08

\title{
Public procurement in Ukraine in the context of international requirements: the way to improve a legal regulation
}

\author{
Viktoriia Holubieva * \\ Yuriy Pyvovar ** \\ Igor Andrushchenko *** \\ Andrii Honchar ****
}

\begin{abstract}
The purpose of the study is to characterize the System of national legal regulation of public procurement of Ukraine, to determine the features of the impact of international law on the Ukrainian procurement system, as well as ways to improve it. The research methodology is based on an integrated intersectoral approach and a comparative approach. The effectiveness of the current legislation of Ukraine on public procurement was determined by means of the "ex post" assessment methodology, and the methodology of legal monitoring, including as a result of the study of court decisions. The results showed that the legal regulation of government procurement on the territory of Ukraine is undergoing significant changes, in connection with the harmonisation of legislation to international (worldwide and regional) standards; the majority part of the WTO GPA and Association Agreement provisions in the field of government procurement has already been implemented or is being implemented by Ukraine. Indeed, taking into account the access to the EU market obtained within the GPA framework, Ukraine has already not so many external incentives for the full compliance with the obligations to harmonize the legislation under the Association Agreement than it was expected at its signing.
\end{abstract}

KEYWORDS: Government policy; Procurement; public finance; international agreements; Public International Law; public administration.

* Ph.D. in law, Associate Professor, Professor of International and European Department, Law Institute, State Higher Educational Institution "Kyiv National Economic University named after Vadym Hetman", Ukraine, ORCID ID: https://orcid.org/0000-0003-3903-3451.E-mail: holubievavic@i.ua

** Professor, Ph.D. in Law, Researcher of Constitutional and Administrative Law Department, Law Faculty, National Aviation University, Ukraine. Scopus ID: 57203992023; Web of Science ID: O-49732016. ORCID ID: https://orcid.org/0000-0001-8258-7930 ${ }^{*}$ Corresponding author: E-mail: pyvovaryi@gmail.com

*** Ph.D. in Law, Associate Professor, National Academy of Internal Affairs, Economic Security and Financial Investigations Department, Kyiv, Ukraine, ORCID: https:/orcid.org/0000-0002-2988-7579

**** Detective of the Crimes Against Person Subdivision, Criminal Investigations Department of the Department of the National Police of Ukraine in Kyiv, Kyiv, Ukraine, ORCID: https://orcid.org/0000$\underline{0003-0922-0096}$

Recibido: 08/06/2021

Aceptado: 28/07/2021 


\section{La contratación pública en Ucrania en el contexto de los requisitos internacionales: la forma de mejorar una regulación legal}

RESUMEN

El propósito del estudio es caracterizar el sistema de regulación jurídica nacional de la contratación pública de Ucrania, para determinar las características de la repercusión del Derecho internacional en el sistema de contratación de Ucrania, así como las formas de mejorarlo. La metodología de investigación se basa en un enfoque intersectorial integrado y un enfoque comparativo. La eficacia de la legislación vigente de Ucrania en materia de contratación pública se determinó mediante la metodología de evaluación "ex post" y la metodología de supervisión jurídica, incluso como resultado del estudio de las decisiones judiciales. Los resultados mostraron que la reglamentación jurídica de la contratación pública en el territorio de Ucrania está experimentando cambios significativos, en relación con la armonización de la legislación con las normas internacionales (mundiales y regionales); la mayor parte de las disposiciones del ACP y del Acuerdo de Asociación de la OMC en la esfera de la contratación pública ya se ha aplicado o está aplicando Ucrania. De hecho, teniendo en cuenta el acceso al mercado de la UE obtenido en el marco del ACP, Ucrania ya no tiene tantos incentivos externos para el pleno cumplimiento de las obligaciones de armonizar la legislación en virtud del Acuerdo de Asociación de lo que se esperaba en el momento de su firma.

PALABRAS CLAVE: Política gubernamental; adquisiciones; finanzas públicas; acuerdos internacionales; Derecho Internacional Público; administración pública

\section{Introduction}

Rationally and effectively organised, competitive government procurement system directly influences the development of each country's economy, stabilisation of commodity markets, reasonable distribution/use of budget funds, provision of goods (services, works) for various social needs, and also leads to fundamental changes in the relations between the state and business entities. All economic entities are interested in competition for government orders, because competitive procurement allows countries to use state funds more efficiently, and more commercial opportunities appear on the market. Government procurement should act as a 
REVISTA DE LA UNIVERSIDAD DEL ZULIA. 3a época. Año $12 \mathrm{~N}^{\circ} 34,2021$ Viktoriia Holubieva et al. /// Public procurement in Ukraine in the context of international ... 106-132 DOI: http://dx.doi.org/10.46925//rdluz.34.08

regulatory mechanism for both competition in the market of quality goods (services, work), and in the anti-corruption efforts (Zakharova et al, 2021). Moreover, globalisation, regionalisation and liberalisation in international trade relations have had an influence on the possibility of including/engaging in government procurement processes not only national economic entities, but also foreign ones, as a consequence - the need to protect their rights (as commodity producers), as well as the interests of the states (in particular, security, economic and other interests), which influenced the creation of the provisions agreed upon between the states (international treaties, decisions of international organisations) in this field and their discussion within the framework of international organisations (e.g. the WTO, the EU). Accordingly, there is a practical significance of the need for regulatory, legal and institutional support/control of the process of government procurement, both nationally and internationally, as well as their concurrency (harmonisation, adaptation). The improvement of legal regulation in government procurement in Ukraine is particularly important, taking into account Ukraine's international commitments in this area and Eurointegration-related aspirations.

The purpose of the study is to characterize the System of national legal regulation of public procurement of Ukraine, to determine the features of the impact of international law on the Ukrainian procurement system, as well as ways to improve it.

To achieve this goal, the author studied the following materials: doctrinal works of scientists, topical articles of practicing experts, Ukrainian legislative acts, regulations of specialized state bodies, international acts and agreements, decisions of the international court, Ukrainian official information registers of public procurement. The main research area of the article is public procurement management. In addition, Ukrainian national legislation and international law were subjected to deep study.

\section{Methods}

The research methodology is based on an integrated intersectoral approach and a comparative approach. A systematic approach and a classification method made it possible to select legal acts regulating public procurement. On the basis of the historical and legal method of cognition, the genesis and subsequent evolution of Ukrainian acts in the context of the 
REVISTA DE LA UNIVERSIDAD DEL ZULIA. 3a época. Año $12 \mathrm{~N}^{\circ} 34,2021$ Viktoriia Holubieva et al. /// Public procurement in Ukraine in the context of international ... 106-132 DOI: http://dx.doi.org/10.46925//rdluz.34.08

development of international legislation on public procurement and trade are investigated. The structural-legal method helped to determine the level of development of the Ukrainian public procurement system in international trade relations. The comparison method allowed the authors to identify features that indicate the compliance of the public procurement system in Ukraine with international principles and norms. The method of critical analysis contributed to the identification of shortcomings in the legal framework for public procurement in Ukraine. The effectiveness of the current legislation of Ukraine on public procurement was determined by means of the "ex post" assessment methodology, and the methodology of legal monitoring, including as a result of the study of court decisions. Analytical and modelling methods contributed to the formulation of proposals for improving the Ukrainian public procurement system.

\section{Results and Discussion}

\subsection{General Characteristics of the Ukrainian Legislation on Public Procurement}

In the current geopolitical and economic relations between the states, in particular the relations with the participation of Ukraine, the availability of an effective and efficient mechanism for the implementation of government procurement becomes important, which is also guaranteed by legal regulation, both at the international (for example, within the WTO and the EU), and at the national (domestic) levels.

In general, to date, Ukraine has the following international obligations in the field of public procurement in accordance with the following documents (in chronological order):

- Free Trade Agreement with the EFTA states (EFTA 2010), which became effective on June 1, 2012 (On the Ratification of the Free Trade Agreement between the EFTA states and Ukraine, the Agreement on Agriculture between the Kingdom of Norway and Ukraine, the Agreement on Agriculture between Iceland and Ukraine and the Agreement on Agriculture between Swiss Confederation and Ukraine, Law of Ukraine, No.4091-VI, 2011, art. 1), containing general provisions on trade in goods (industrial, agricultural, fish and marine products), services and dispute settlement; 
REVISTA DE LA UNIVERSIDAD DEL ZULIA. 3a época. Año $12 \mathrm{~N}^{\circ} 34,2021$ Viktoriia Holubieva et al. /// Public procurement in Ukraine in the context of international ... 106-132 DOI: http://dx.doi.org/10.46925//rdluz.34.08

- Association Agreement between the European Union, the European Atomic Energy Community and their Member States on the One Part, and Ukraine, on the Other Part of 2014. (Chapter 8 of Section IV (Art. 148-156 and Annex XXI; according to Annex XXI-A, the Indicative Diagram of Institutional reforms, adaptation of legislation and market access, which is divided into several stages, is established) (VRU, 2014);

- WTO Agreement on Government Procurement of 1994 (WTO, 1994) (Agreement on Government Procurement, hereinafter referred to as GPA) (VRU, 2016).

In addition, one cannot ignore the UNCITRAL Model Law "On Procurement of Goods, Construction and Services" dd. June 17, 1994 (UNCITRAL, 1995) and the OECD Principles for Integrity in Public Procurement 2009 (OECD, 2009), which are an example of the "soft law", and the generalized international and national experience and practical developments in the field of government procurement under free market conditions, as well as the acknowledgement of urgency of the proper state regulation in this area. The above-mentioned developments of the UNCITRAL and OECD (Ukraine is not a member of the OECD) can informally and instructively influence on domestic state actions of countries (including Ukraine), when they create /reform their national legal and institutional mechanism for the budget allocation.

It should be noted that the terms "government/state procurement" and "public procurement" are used as synonyms. The term "government procurement" is used in the official Ukrainian text of the Association Agreement, and the WTO Agreement on Government Procurement, while in the national legislation, the term "public procurement" is used since 2015, and in the first place - in the Law of Ukraine "On Public Procurement" (VRU, 2015).

In fact, the legislation of Ukraine related to the government procurement is continuously developing and systematising, but nonetheless, there are the existing and potential risks and problems of functioning, which are to be solved. That is, one of the significant problems of the government procurement system of Ukraine is the considerable scope and "relative novelty" of the regulatory framework. Constant change of statutory instruments is one of the main problems of the system of state procurement, which leads to ambiguous interpretation of principles and rules of public procurement, as well as to ineffective enforcement. One may say 
REVISTA DE LA UNIVERSIDAD DEL ZULIA. 3é época. Año 12 N$^{\circ}$ 34, 2021 Viktoriia Holubieva et al. /// Public procurement in Ukraine in the context of international ... 106-132 DOI: http://dx.doi.org/10.46925//rdluz.34.08

that recently the legislation on government procurement has been drastically changing, which in practice leads to numerous conflicts and difficulties in practical activities of business entities.

The system of regulatory management of public procurement in Ukraine is characterised by an extensive system of statutory instruments, mainly by delegated legislation, regulating certain highly specialised issues related to the development and detailed elaboration of the provisions of On Public Procurement, Law of Ukraine, of Dec. 25, 2015, No.922-VIII.

The basis of the Ukrainian legislation in public procurement is made up of the following laws and regulations:

a) On Public Procurement, Law of Ukraine, of Dec. 25, 2015, No.922-VIII, which encapsulated the legal and economic principles of purchase of goods, works and services to meet the requirements of the state and the local community, as well as the procedure for their implementation (Art. 1), which came into force for all customers in Aug. 1, 2016 (regulatory acts in the similar sense exist in almost all countries of the world);

b) On Sanctions, Law of Ukraine, of Aug. 14, 2014, No.1644-VII, prohibiting government procurement of goods, works and services from the state-owned legal entities being the residents of a foreign country and legal persons, a share of the registered capital of which is the property of a foreign country, as well as government procurement from other entities engaged in the sale of goods, works, services originating from a foreign country to which sanctions have been applied (Art. 4);

c) On Prevention of Corruption, Law of Ukraine, of Oct. 14, 2014, No.1700-VII, stating that the anti-corruption program must be approved by the heads of the legal entities, being the participants of the preliminary qualification and procurement procedures in accordance with the Law of Ukraine On Government Procurement, if the value of purchase of goods, service (services), and work equals or exceeds $20 \mathrm{mln}$ hryvnias (Art. 62);

d) On Peculiarities of Procurement of Goods, Works and Services for Ensuring Defence Needs, Law of Ukraine, of May 12, 2016 No.1356-VIII, specifies the implementation procedures for the procurement of goods, works and services to ensure meeting of defence needs for the special period, the period of the anti-terrorist operation, during the period of the state of emergency (Art. 1); 
REVISTA DE LA UNIVERSIDAD DEL ZULIA. 3a época. Año $12 \mathrm{~N}^{\circ} 34,2021$ Viktoriia Holubieva et al. /// Public procurement in Ukraine in the context of international ... 106-132 DOI: http://dx.doi.org/10.46925//rdluz.34.08

e) On Approval of the Procedure for the Electronic Procurement System Operation and the Authorisation of Electronic Platforms, Resolution of the Cabinet of Ministers of Ukraine, of Feb. 24, 2016, No.166 - concerning the operation of the e-procurement system, the procedure of authorisation of electronic platforms, conditions and cases of disconnection of electronic platforms from the e-procurement system, the requirements to electronic platforms and the responsibility of the operators of authorised electronic platforms;

f) On the Strategy of Reforming Public Procurement System (the "Roadmap" according to Article 152:2 of the Association Agreement), Resolution of the Cabinet of Ministers of Ukraine, of Feb. 24, 2016, No. 175-p, specified the fundamentals of harmonisation of national legislation to the EU rules, the adaptation of key concepts, notions and bringing the procurement procedures in compliance with international standards. Moreover, Resolutions of the Cabinet of Ministers of Ukraine: On the Prepayment of Goods, Works and Services Purchased for Budget Funds of Apr. 23, 2014, No.117, is of great importance; On Complaint Filing Fees Setting of Mar. 23, 2016, No.291; On Approval of the Procedure of Using Funds Provided by the State Budget for Financial Support to Ensure the Functioning of the Government Procurement Web-Portal of July 22, 2016, No.467;

g) Orders of the Ministry of Economic Development and Trade of 2016: On the Procedure of Publication of Information on Public Procurement of Mar. 18, 2016, No.477; On Allocating the Web Portal of the Authorised Body for Procurement as Part of the Electronic Procurement System and Ensuring of Its Functioning (ProZorro) of Mar. 18, 2016, No.473; On Approval of the Forms of Documents in Public Procurement of Mar. 22, 2016, No.490; On Approval of Samples of Tender Documents of Apr. 13, 2016, No.680; On Approval of the Procedure for Determining the Procurement Item of Mar. 17, 2016, No.454; On Approval of a Sample Provision on the Tender Committee or Authorised Person (Persons) of Mar. 30, 2016, No.557;

On Approval of the Instruction Concerning the Procedure for Using the Electronic Procurement System in Case of Procurement, the Cost of Which is Less than the Cost specified in Paragraphs 2 and 3 of Part 1 of Article 2 of the Law of Ukraine "On Public Procurement", Order of the Prozorro State Enterprise, of Mar. 19, 2019, No.10 and others. 
REVISTA DE LA UNIVERSIDAD DEL ZULIA. 3a época. Año $12 \mathrm{~N}^{\circ} 34,2021$ Viktoriia Holubieva et al. /// Public procurement in Ukraine in the context of international ... 106-132 DOI: http://dx.doi.org/10.46925//rdluz.34.08

2.2. General Characteristics and Special Features of the Legal and Regulatory Framework Covering Government Procurement in the Framework of the WTO

For a long time, the regulation of government procurement was outside the GATT1947/WTO (WTO, 1947) system and did not include the extension of the most favoured nation treatment regime to public procurement procedures. Within the Tokyo Round of multilateral trade negotiations (1973-1979), on April 12, 1979, the Government Procurement Agreement was adopted, and entered into force on Jan. 1, 1981; later it was in force as revised or amended on February 2, 1987, and encapsulated in goods only public procurement the most favoured nation treatment, only for organisations subordinate to the central government bodies. Subsequently, this Agreement was revised during the Uruguay Round of Negotiations in 1994, and came into force on January 1, 1996. However, due to the fact that the WTO brings together a large number of countries, both developed and those developing, the issue of creating the government procurement rules mandatory for all is a problem, because this sector is not subject to legal regulation of "WTO Multilateral Agreements". Accordingly, when joining, the countries take the responsibility of execution of the "Multilateral trade agreements", contained in Annexes 1, 1B, 1C, 2, 3 to the Marrakesh Agreement on the creation of the WTO (paragraph 1 of art. XII) (WTO, 1994b). The scope of government procurement is regulated by the Government Procurement Agreement of Apr. 15, 1994 (hereinafter - GPA or WTO GPA), which refers to a limited number of agreements contained in Annex 4, that is, it can be acceded by individual WTO member states, at will (GPA art. XXIV:2).

Conditions for the WTO-member's accession to the Agreement on Government Procurement are agreed upon during negotiations. While joining the Agreement, the Government of the WTO-member should ensure the compliance of the national legislation, administrative procedures, rules and practices in respect of public procurement with the GPA provisions (Art. XXIV:5). A formal procedure for the accession to the Agreement, which stipulates the submission by an applicant of an offer as concerns the GPA coverage of its procurement and negotiations with the parties to the Agreement, has been established.

It should be noted that the accession of new parties to the GPA is extremely slow, most countries acceded it in 1996. Of the 164 WTO member-states (WTO, 2016), 48 WTO member- 
REVISTA DE LA UNIVERSIDAD DEL ZULIA. 3ㄹ época. Año $12 \mathrm{~N}^{\circ}$ 34, 2021 Viktoriia Holubieva et al. /// Public procurement in Ukraine in the context of international ... 106-132 DOI: http://dx.doi.org/10.46925//rdluz.34.08

states are the parties to the GPA (including Armenia, Hong Kong, Israel, Canada, New Zealand, Norway, Republic of Korea, Singapore, USA, Switzerland, Japan, Ukraine, the EU and 28 member states, covered by the GPA as one part, the customs territory), another 4 international organisations (namely: IMF, OECD, UNCTAD/WTO-ITC) and 34 WTO members participate in the GPA Committee as observers, 9 of which are in the process of acceding the GPA. The WTO estimates a total volume of the government procurement market at 1.7 trillion US Dollars annually (WTO, 2020).

The WTO policy is to contribute to the formation of an effective global public procurement market. The purpose of the GPA is to achieve greater liberalisation and expansion of world trade; elimination of discrimination; ensuring the transparency of laws, regulations, procedures and practices relating to state procurement and the improvement of the international basis for the world trade. The GPA contains standards that form the basis for institutional reforms at the national and international levels, and consists of two parts: a) general rules and responsibilities (mostly with regard to the procedures for competitive bidding); b) the annexes of the national authorities in each member state, whose procurement is subject to the GPA.

In 2012 the GPA was amended according to the Protocol on Amendments to the WTO Government Procurement Agreement (WTO, 2012) (art. II) concerning the prevention and counteraction of corruption in the government procurement.

The most important principles enshrined in the GPA are the principles of national treatment and non-discrimination. According to art. III:l GPA requires the use of both the principle of national treatment, and the principle of most favoured nation in government procurement (art. III), and for developing countries, the GPA provides for a special and differential treatment (art. V).

Among the purely economic and organizational advantages, it is usually noted that for entering the foreign government procurement market, a foreign participant does not need to have a local office, spend on advertising, and be engaged in retail trade. The main thing the OECD draws attention is the integrity of the public government procurement process (OECD, 2009: 
REVISTA DE LA UNIVERSIDAD DEL ZULIA. 3a época. Año $12 \mathrm{~N}^{\circ} 34,2021$ Viktoriia Holubieva et al. /// Public procurement in Ukraine in the context of international ... 106-132 DOI: http://dx.doi.org/10.46925//rdluz.34.08

10), consisting of types, stages /steps /phases, and influenced by economic, legal, organizational, political, social, environmental and other factors.

It should be noted that the Agreement on Government Procurement covers only a part of public procurement of the contracting countries, namely that:

Is carried out by procuring organizations identified by each Member, that is, ones subordinated to central government bodies, regional (local) authorities, as well as other organizations, including utility providers;

Has relation to goods and services designated by the Member, including construction ones;

Has relation to procurement contracts, for an amount not less than corresponding limits / cost thresholds (Article I:4).

The Agreement applies to any contracts (for example, purchase, leasing, rental ones, etc., including any combination of products or services) with respect to public/government procurement (Art. I:2), the value of which exceeds the established limits / cost thresholds fixed in Appendices of each Party to the GPA (Art. I:1). In Ukraine (WTO GPA/133 (2015)), the purchase cost threshold is as follows:

- for goods and services acquired by organizations subordinated to central government bodies: - SDR 130.000, and for construction services: - SDR 5.000.000 (Appendix A, Appendix I, Appendix 1);

- for goods and services acquired by other government authorities - SDR 200.000, and for construction services: - SDR 5.000.000 (Appendix A, Appendix I, Appendix 2);

- for those acquired by other institutions, enterprises, and organizations in the field of public/social works, goods and services: - SDR 400.000, and for construction services: - SDR 5.000.000 (Appendix A, Appendix I, Appendix 3).

It should separately be noted that these limits / cost thresholds in the rough were set out in Appendices of the most part of the States-Parties to the Agreement.

The Government Procurement Agreement contains the detailed procedural/tendering requirements that must be observed by procurement entities. The procedural requirements are aimed at ensuring the guaranteed access to procurement covered by the Agreement and creating 
REVISTA DE LA UNIVERSIDAD DEL ZULIA. 3a época. Año $12 \mathrm{~N}^{\circ} 34,2021$

Viktoriia Holubieva et al. /// Public procurement in Ukraine in the context of international ... 106-132

DOI: http://dx.doi.org/10.46925//rdluz.34.08

the level playing field for domestic and foreign suppliers in their competition for government procurement contracts. The Agreement allows to conduct the bidding procedures of three types (Article VII):

- open: - that is, any interested supplier may submit his offer;

- selective (Article X): - that, according to which only suppliers invited by a procurement entity, for example from the annual list of qualified suppliers (Article IX:9), may submit their offer;

- Limited (Article XV): - that where a procurement entity contacts potential suppliers individually in cases specified in Article XV of the GPA.

Notably, in accordance with the OECD First Public Procurement Principle, the appropriate degree of transparency is ensured across the whole procurement process, with a view to promoting the fair and equitable involvement of potential participants/suppliers (2009: $11)$.

Also, in the Agreement on Government Procurement, there are entrenched the requirements ensuring transparency and the non-discriminatory determination of qualified suppliers (Article VIII), in addition to the pre-determined, limited and objective conditions for the participation in bidding (Article VIII: 3,4 ), as well as the sufficiency (reality of terms) for any actions related to the organization and conduct of procurement procedures and performance of contracts concluded following their results (Articles VIII (c); IX: 9, 10; XI: 1, 3).

The tender documentation provided by a procurement entity must contain all necessary information with respect to an intended procurement, so that potential suppliers will be able to submit an appropriate tender offer (Articles IX, XII).

The agreement defines rules to conduct the procedure for the announcement, receipt and opening of tender offers. The main purpose of such rules is to ensure transparency, as well as the fair, competitive and non-discriminatory conduct of the procurement procedure at all and every stages /steps /phases of the cycle of government/public procurement, regardless of its type. Thus, during the open or selective tender procedure, the conditions for opening of tender offers precisely on the day, at the time and in the place established by the tender documentation, and requirements regarding the national regime and non-discrimination towards the acceptance and 
REVISTA DE LA UNIVERSIDAD DEL ZULIA. 3é época. Año 12 N$^{\circ}$ 34, 2021 Viktoriia Holubieva et al. /// Public procurement in Ukraine in the context of international ... 106-132 DOI: http://dx.doi.org/10.46925//rdluz.34.08

opening of offers, as well as requirements /guarantees to have a procurement contract concluded with a supplier, must be ensured (Article XIII).

The Agreement prohibits to apply measures as for promoting the local development, or improving the balance of payments through localization, and licensing of technology, investment requirements, conditions for the countertrade, or similar requirements (Article XVI). However, developing countries can, under certain conditions, apply similar measures.

As concerns technical specifications (Article VI) laying down the characteristics of products or services (quality, safety, dimensions, packaging, marking, etc.), production processes and requirements relating to conformity assessment procedures prescribed by procurement entities, the Agreement establishes the requirement to apply them in such a way that no additional and unnecessary barriers to international trade are created (Article XII: 2 (f), (g)). Moreover, they must be based on existing international standards or, in their absence, on national technical regulations and standards. But, for example, in Germany and the Netherlands, there is entrenched the requirement that technical specifications should be based solely on national standards, which discriminates to some extent foreign suppliers (Pokrovskaya \& Uskova, 2008: 36).

The WTO GPA does not directly regulate the issue of the "sustainable" / "green" government procurement, but countries can apply the "environmentally-appropriate" conditions only through the possibility of establishing technical requirements for products/services and their suppliers. Also, the countries-parties to the GPA are not prohibited from introducing more specific provisions of the national legislation in the field of government procurement in order to ensure/comply with the "environmental and social responsibility" (Shadrina \& Romodina, 2017: 160).

Due to the fact that government procurement, though unified by the common rules and obligations of the member states, nevertheless, the regulation of this sphere is carried out in accordance with national legislation. For the convenience and efficiency of government procurement, given the remoteness of the various countries and the location of national authorities making the order, most of the government procurement is currently being executed 
REVISTA DE LA UNIVERSIDAD DEL ZULIA. 3ㄹ época. Año $12 \mathrm{~N}^{\circ}$ 34, 2021 Viktoriia Holubieva et al. /// Public procurement in Ukraine in the context of international ... 106-132 DOI: http://dx.doi.org/10.46925//rdluz.34.08

electronically via the Internet. Each GPA member state has a national platform for the efficient government procurement (WTO, 2020b).

The Parties to the GPA are obliged to promptly publish any regulatory legal acts, judgments, administrative rules of the general application, as well as any procedure (including standard contract terms and conditions) as regards government procurements in a relevant publicly-accessible specific publication, the list of which, for example for Ukraine, is enshrined in Appendix II to the WTO GPA/133 dd. November 1l, 2015. In addition, each Party to the WTO GPA must annually report statistics of its purchases made under the Agreement to the Committee on Government Procurement (Article XIX:5). This statistical data contains the information about the number and total volume of contracts being lower and higher than the price threshold, including with the breakdown by types of procurement entities, groups of products and services, as well as of those concluded under the restricted procedure.

Before the start of the bidding procedure, the Parties to the Agreement are obliged to publish a tender offer (according to Articles VI, VII, IX:7, XVI:2), that is, the invitation to participate in a tender, in a publicly-accessible electronic or print medium/resource used by the Parties for the publication of notices (for Ukraine, this is Appendix III to the WTO GPA/133 dd. 11.11.2015). Not later than 72 days after the contract is concluded with a supplier, a procurement entity must also inform about the procurement award (Article XVIII). Such notice should include the information about the type and amount of products or services under the contract, data on a winning tenderer, the contract price or the highest and lowest offers that were taken into account while making the award towards the contract.

Furthermore (Article XIX:2), at the request of any supplier of the Party to the Agreement, a procurement entity must provide with explanations towards its procurement procedure, reasons for the refusal given to a supplier to include him in the qualifying list, characteristics and advantages of a selected tender offer, etc. In this case, the conditions for the confidentiality of certain information, for example, concerning considerations to ensure public interests and commercial secrecy, as well as to maintain conditions for the fair competition among suppliers, must be observed. (Taking into account the OECD Second Public Procurement Principle consisting in the fact that governments should maximize transparency in a competitive tender 
REVISTA DE LA UNIVERSIDAD DEL ZULIA. 3a época. Año $12 \mathrm{~N}^{\circ} 34,2021$ Viktoriia Holubieva et al. /// Public procurement in Ukraine in the context of international ... 106-132 DOI: http://dx.doi.org/10.46925//rdluz.34.08

and apply preventive measures to improve the integrity, especially with regard to cases connected with emergency urgent situations and national security) (OECD, 2009: 11). The Government of the Party to the Agreement, a supplier of which did not win in a tender, may also submit a request for additional information in order to verify the fairness and impartiality of a tender. In particular, in Ukraine the web-resource addresses or addresses, at which the Parties publish the statistical information on procurement according to Article XVI:5, and notices on contracts concluded according to Article XVI:6, are captured in Appendix IV to the WTO GPA/133 dd. November 11, 2015.

One of the key GPA provisions is to enable vendors to challenge actions that are in contradiction to its provisions (by settling disputes (Article XXII) and appeal procedures (Article XX)). And since the GPA is one of the WTO agreements, all disputes arising as a result of its execution may also be settled through the dispute settlement procedure provided for in the Dispute Settlement Understanding of 1994 (WTO, 1994c). However, at the same time, the settlement of disputes under the WTO GPA has its own particularities and is also subject to special rules. The most important rules from them are those concerning:

- the inability to terminate concessions or other obligations under the GPA within the procedure governing the settlement of disputes under any other WTO agreements, and vice versa, the inability to terminate concessions or other obligations under any other WTO agreements within the procedure governing the settlement of disputes under the GPA (Article XXII:7);

- the right of the Dispute Settlement Body to allow consultations between the Parties to the Agreement on disputes, under which it seems to be impossible to withdraw measures that violate the provisions of the Agreement (Article XXII:3).

One of the features of the GPA is the requirement for the Parties to the Agreement to establish a non-discriminatory, transparent and effective internal challenge procedure (Article $\mathrm{XX}$ ). Suppliers who have doubts about the compliance with the GPA requirements in the procurement process may apply to the independent court on the territory of the Party. The Party to the WTO GPA may delegate authorities to consider a supplier's complaint to the national judicial instance, or an independent and impartial supervisory body. A body considering the 
REVISTA DE LA UNIVERSIDAD DEL ZULIA. 3a época. Año $12 \mathrm{~N}^{\circ} 34,2021$ Viktoriia Holubieva et al. /// Public procurement in Ukraine in the context of international ... 106-132 DOI: http://dx.doi.org/10.46925//rdluz.34.08

complaint may take a decision to eliminate breaches of the Agreement, or to compensate a supplier for costs related to the preparation for a tender, or a notice of protest. A decision on the elimination of breaches of the Agreement may envisage urgent temporary measures, including the termination of the bidding procedure. For the whole effective period of the GPA, only four disputes in the field of government procurement were settled, namely (WTO, 2020c):

DS163 - Claimant: USA. Defendant: Republic of Korea. Third parties: EU, Japan. - The report of the group of experts is approved, no action has been taken since on June 19, 2000;

DS95 - Claimant: Japan. Respondent: USA. The powers of the group of experts terminated on Feb. 11, 2000;

DS88 - Claimant: EU. Respondent: USA. Third Party: Japan. The powers of the group of experts terminated on Feb. 11, 2000;

DS73 - Claimant: EU. Respondent: Japan. Suspended (mutually agreed solution) on July 31, 1997.

The institutional mechanism/body of the Government Procurement Agreement is the Committee on Government Procurement (Article XXI), which includes representatives of all the Parties to the Agreement. The Committee shall elect its Chairman and Vice-Chairman and shall conduct meetings not less than once a year. The authorities of the Committee cover:

- the annual review of the implementation and operation of the Agreement;

- the annual report on the implementation of the Agreement to the WTO General Council, as well as the Parties to the GPA;

- the establishment of subsidiary bodies (for example: the Working Group on Transparency in Government Procurement), the Working Commission on matters of the GATS Rules, the Work Program on Collection and Reporting of Statistical Data, etc.;

- the facilitation of consultations between the Parties on any issues related to the implementation of the Agreement;

- the definition of directions for the further development of the Agreement, making amendments and additions thereto;

- the generalization and analysis of notifications and statistical data provided by the Parties to the Agreement. 
REVISTA DE LA UNIVERSIDAD DEL ZULIA. 3a época. Año $12 \mathrm{~N}^{\circ} 34,2021$ Viktoriia Holubieva et al. /// Public procurement in Ukraine in the context of international ... 106-132 DOI: http://dx.doi.org/10.46925//rdluz.34.08

The WTO «eGPA» is the official WTO GPA portal and the only point of information and entry for domestic and foreign exporters, chambers of commerce and industry, businessassociations, business-schools, electronic platforms, other ministries and governmental bodies, and mass media communications (WTO, 2020d).

As a factor of the performance by the States of their international obligations in a certain area (including government /public procurement), it might be appropriate to envisage, in the GPA (as part of the annual reviews of the implementation and operation of the Agreement) and/or in the Trade Policy Review Mechanism (WTO, 1994d), obligations in materials (reports, reviews, analytical data, separate sections, etc.) not only to reflect the fulfillment /observance by the Parties of the GPA provisions, but also to indicate ways to avoid /evade them at the national level, specific violations, abuses (their quantitative indicators, systemacity, etc.). This would enable countries to independently improve, more actively and responsibly, at the national level and in the unilateral manner, their organizational-legal mechanism/system of government procurement, within the framework of the principles and provisions entrenched in the WTO GPA.

The main areas in the work of the GPA contracting States, in the field of government /public procurement, for the near future are as follows:

- development and use of the unified methodology for collecting information and reporting;

- further expansion of using the Open Contracting Data Standard, OCDS, which will significantly increase transparency and availability of the information about public procurement. (as a matter of fact, ProZorro Electronic Public Procurement System is built exactly on the basis of using this standard).

It should be noted that the international and legal peculiarity of WTO law is that member states are obliged to ensure the conformity of its laws, regulations and administrative procedures with the WTO agreements. The GPA establishes only the basic rules that countries must apply at government procurement at the international and national levels within the framework of the WTO. GPA does not regulate in full and in detail the whole procedure of government procurement, leaving a choice in building this system and formalising individual 
REVISTA DE LA UNIVERSIDAD DEL ZULIA. 3é época. Año 12 N$^{\circ}$ 34, 2021 Viktoriia Holubieva et al. /// Public procurement in Ukraine in the context of international ... 106-132 DOI: http://dx.doi.org/10.46925//rdluz.34.08

elements to the discretion of each state, depending on the national features of the economic system.

After years of negotiations and Ukraine's activity to bring the state of the economy and legislation into compliance with WTO requirements, on Feb. 5, 2008 (WTO, 2008), the Protocol on the Accession of Ukraine to the WTO was signed (art. 1) (VRU, 2008), in accordance with the procedures of May 16, 2008. Ukraine became a full member of this Organisation (art. 1) (WTO, 2020d). Due to the fact that the GPA is an agreement with a limited number of parties to it (Annex 4), in 2009 Ukraine started a separate procedure to accede to this Agreement, the period of validity of which ended in 2016. Ukraine acceded to the GPA, concluded on Apr. 15, 1994 in Marrakesh, as amended by the Protocol to it from Mar. 30, 2012 (Geneva), based on the Decision of the Committee on Government Procurement of the WTO GPA/133 dated on Nov. 16, 2015 (art. 2), including Annexes A and B to this Decision (art. 1) (VRU, 2016).

Due to Ukraine's accession to the GPA, the office of GPA in UA, a pilot project office set up by the Ministry of Economic Development and Trade of Ukraine with its partners, was opened. The goal of the GPA in UA office is to provide support and advice to Ukrainian companies participating in international government procurement of GPA states and importers from GPA member states in terms of their participation in government procurement in Ukraine, as well as the analysis of the obstacles and assistance in resolving disputes. It should be noted that the idea of providing advisory support was adopted by Ukraine from the EU, which manages the advisory network-the European Network of Enterprises (EEN), established on the basis of national Chambers of Trade, agencies for development and universities. As a rule, all these diverse structures offer not only government procurement advice but also other information services on various aspects of EU law in the field of state procurement.

On February 25-27, 2019, within the framework of the Meeting of the WTO Committee on Government Procurement, Ukraine was elected, for the first time in history of its membership in the WTO, as a Presiding Country of the Work Program on Collection and Reporting of Statistical Data. The previous presiding country of this Program was the USA. This 
REVISTA DE LA UNIVERSIDAD DEL ZULIA. 3é época. Año 12 N$^{\circ}$ 34, 2021 Viktoriia Holubieva et al. /// Public procurement in Ukraine in the context of international ... 106-132 DOI: http://dx.doi.org/10.46925//rdluz.34.08

event is a certain confidence in Ukraine on the part of the world community and recognition of our achievements in the field of regulating government procurement.

Given that Ukraine has recently become a party to the GPA (in 2016), the Ukrainian business entities are only starting to use the opportunities provided by the GPA, and as a result an active consulting is arranged for potential national suppliers regarding their participation in international government procurement, foreign businesses are engaged in national procurement. Ukraine's participation in the system of state procurement within the framework of the WTO has just begun and needs to be elaborated. Ukraine's accession to the GPA is of great practical significance to stabilize the national economy, contributing to the expansion of markets for government procurement, as commodity markets around the world are now opening for the national suppliers, which will stimulate the production, but on the other hand, lead to the increased competition on the domestic market of the country.

Depending on the participation of the Parties in the WTO Agreement on Government Procurement, the following types of agreements (regulations) on the free trade and regional economic integration, which include the provisions on government procurement, can be conventionally distinguished:

Agreements concluded between the Parties to the GPA for government procurement (in particular, the Association Agreement between Ukraine and the EU of 2014), in which a more liberal regime than that the GPA envisages is provided (for example: owing to separate more detailed procedural provisions; by expanding the list of goods and services, etc.);

Regional trade agreements between the states participating in the GPA for government procurement, and countries that are not parties to this Agreement (which affects the bilateral regulation of the field of government procurement).

To sum up, it should be noted that the legal regulation of government procurement on the territory of Ukraine is undergoing significant changes, in connection with the harmonisation of legislation to international (worldwide and regional) standards, this stipulates the adoption of a large number of regulatory acts. Constant changes in legislation lead to complications in the laws application in practice. 
REVISTA DE LA UNIVERSIDAD DEL ZULIA. 3a época. Año $12 \mathrm{~N}^{\circ} 34,2021$ Viktoriia Holubieva et al. /// Public procurement in Ukraine in the context of international ... 106-132 DOI: http://dx.doi.org/10.46925//rdluz.34.08

2.3. Ukraine's International Obligations in the Field of Government Procurement According to the Association Agreement between Ukraine and the EU of 2014

According to art. XI of the Marrakesh Agreement on the Establishment of the WTO, the EU as a customs territory and Ukraine as a state (art. XII), are members of the WTO. As a result, having signed the Association Agreement (EU-Ukraine, 2014), the parties to it (Ukraine and the EU) must perform with the international obligations arising from the participation, both in the GPA and those associated with the WTO membership, including the Government Procurement Agreement.

The EU and Ukraine, at the development of the Association Agreement have performed their international obligations, due to the WTO membership, and, in general, with no repetitions, have complemented and elaborated the GPA provisions at the regional level. One of the most significant trends of reforming the government procurement system is to ensure the stability and predictability of the regulatory framework on the basis of the harmonisation of national legislation to the EU rules, the adaptation of key concepts, and notions and bringing procurement procedures in line with international standards.

It should be noted that according to the chronology of events, before the conclusion of the regional international treaty - the Association Agreement between Ukraine and the EU in 2014, the accession of Ukraine to the WTO Agreement on Government Procurement was preceded in 2016 (potentially a worldwide international treaty). On the one hand, the provisions of the Association Agreement in the field of government procurement influenced on the position of the EC and Ukraine in the negotiation process regarding the WTO GPA; on the other hand, the GPA influenced on the adjustment of some obligations of the Parties in the Association Agreement in 2018.

The Association Agreement between Ukraine and the EC (Chapter 8 (Articles 148-156) of Section IV and Appendix XXI) envisages "ensuring the mutual access to the public procurement markets, based on the principle of the national regime at the whole-of-government, regional and local levels for state contracts and concession agreements in traditional economy branches, as well as in public utilities" (Article 148). 
REVISTA DE LA UNIVERSIDAD DEL ZULIA. 3época. Año $12 \mathrm{~N}^{\circ}$ 34, 2021 Viktoriia Holubieva et al. /// Public procurement in Ukraine in the context of international ... 106-132 DOI: http://dx.doi.org/10.46925//rdluz.34.08

As distinguished from the market of goods against the government procurement market, the Association Agreement stipulates not the asymmetric opening of the market on the EU part, but the symmetric mutual access to the market of two parties, after bringing the national legislation by Ukraine in compliance with the EU regulations (Article 154). The Association Agreement envisages the mutually gradual (Article 148) five-stage (Appendix XXI) access to the government procurement market, subject to the fulfillment by Ukraine of the so-called "homework" (EU-Ukraine, 2019) (with the possibility, upon completion, of the further mutual deeper access to the government procurement markets (Article 154(4))). The WTO Agreement on Government Procurement does not stipulate the "homework", since all is sues are agreed upon before its signing in the negotiation process.

The Association Agreement explicitly links the access to the EU public procurement market with the actions of Ukraine regarding the approximation of the national legislation to the EU government procurement rules (Article 148). In particular, Ukraine should define a central executive body responsible for government procurement policies (Article 150:2(a)), and a separate impartial and independent appeal body for reviewing decisions taken by customers in the procurement process (Article 150:2(b)). In conducting procurement, the principles of non-discrimination, equal treatment, transparency and proportionality must be observed (Article 151:1). Ukraine should bring its legislation into proximity with the requirements of the EU Directives regulating government procurement; however, these directives should not be fulfilled completely or instantly (Article 153:2). Appendices from XXI-B to XXI-N divide these Directives into several types of elements: "basic", "mandatory", "optional" (i.e. provisions that are not mandatory, but recommended for approximation) and those, "which do not fall under the scope of the legislative adaptation". It is worth noting that Ukraine has already fulfilled or is in the process of fulfillment of the above conditions (details will be discussed later).

It is worth noting that in $22 \mathrm{EU}$ countries there are both special State Programs (Plans) for the Development, for example, "green" government procurement (France, Germany, Lithuania), and general State Programs for the environmental protection, which determine the role of government procurement in the achievement of goals and objectives (e.g. in Latvia). Development of the mentioned programs in Ukraine is currently a pending issue, because the 
REVISTA DE LA UNIVERSIDAD DEL ZULIA. 3a época. Año $12 \mathrm{~N}^{\circ} 34,2021$ Viktoriia Holubieva et al. /// Public procurement in Ukraine in the context of international ... 106-132 DOI: http://dx.doi.org/10.46925//rdluz.34.08

only plan for further development of public procurement is now the Government Procurement Reformation Strategy ("Roadmap" - art. 152:2 of the Association Agreement), which is designed for the staged harmonisation of national legislation to the EU requirements, rather than for the implementation of domestic and national development plan, and in particular it specifies:

1) the harmonisation of Ukrainian legislation in the field of government procurement with the relevant EU aquis standards according to Chapter 8 of section IV and Annex XXI to the Association Agreement (art. 153);

2) institutional development, proper financial and logistics management and staffing of the authorised body (namely, the Ministry of Economic Development and Trade of Ukraine), as well as the independent supervisory authority for the protection of the rights of subjects of government procurement, optimisation of the interaction of regulatory and supervisory bodies in the field of government procurement and public finances management;

3) creation and development of electronic procurement system considering the requirements and standards of the EU and best international practice (for example: On the Government Procurement Reformation Strategy ("Roadmap") of Feb. 24, 2016 No.175-p, Resolution of the Cabinet of Ministers of Ukraine);

4) development of the system of professional training of specialists in public procurement and professionalization in the field of government procurement (Prozorro, Infobox, n.d.);

5) international cooperation in the field of government procurement and improvement of the image of Ukraine in the international arena as a state with a modern system of state procurement.

In order to ensure the proper organisation and implementation of tasks in the field of European integration and implementation of the Association Agreement, the Government Office for the Coordination of European and Euro-Atlantic Integration was established, consisting of the Secretariat of the Cabinet of Ministers of Ukraine (For example: Resolutions of the Cabinet of Ministers of Ukraine: On the Government Office for European and Euro-Atlantic Integration of Aug. 13, 2014 No.346 \& On the Government Office for the Coordination of European and Euro-Atlantic Integration of Oct. 4, 2017 No.759). 
REVISTA DE LA UNIVERSIDAD DEL ZULIA. 3a época. Año $12 \mathrm{~N}^{\circ} 34,2021$ Viktoriia Holubieva et al. /// Public procurement in Ukraine in the context of international ... 106-132 DOI: http://dx.doi.org/10.46925//rdluz.34.08

Among the most prominent innovations in the field of government procurement in Ukraine, the "ProZorro" system should be noted, which consists of a single database, using the NOSQL open source, and a single centralised system of electronic auctions, which are accessed via six separate commercial platforms, which receive revenue through the fees, paid by the entities participating in the auctions. Transparency and avoidance of corruption, in particular, are supported by clear tariffs for the use of the ProZorro electronic system. Regarding the public administration of the given electronic system, the ProZorro electronic system of government procurement, initially based on non-governmental principles, has finally turned into a state institution (MEDTU, 2016).

The main objectives of the electronic system are: eradication and systemic prevention of corruption; transparency of government procurement; the inadmissibility of discrimination and the objective evaluation of bid applications; simplicity and ease of procedures application; transition to electronic document flow; complete reporting and analysis of all state procurement.

It should also be noted that the introduced ProZorro system of electronic public procurement has been recognised worldwide. The Ministry of Economic Development and Trade of Ukraine received the World Procurement Awards for the creation and implementation of an electronic system with a unique architecture. The Ministry of Economic Development of Ukraine and ProZorro were nominated in the Public (Government) Procurement ("Public Sector") category. Among the other nominees in this category there were: Ministry of Justice of Great Britain with the competition transformation, the Department of Education of the New South Wales, Australia, with its own solutions in the area of procurement, and the Executive Office of the President of the USA with their P200 procurement service. It has been noted that the ProZorro practice confirms/evidences the effectiveness of the reforms, which are based on the Government-Business-Community triangle, and due to the support of a reputable international anti-corruption organisation - Transparency International, and the WNISEF foundation, EBRD, the German Government and other partners, the ProZorro system was able to demonstrate positive results already at the initial stage. It should be noted that the EU widely applies the government procurement procedure in the form of an electronic auction. EU state 
REVISTA DE LA UNIVERSIDAD DEL ZULIA. 3a época. Año $12 \mathrm{~N}^{\circ} 34,2021$ Viktoriia Holubieva et al. /// Public procurement in Ukraine in the context of international ... 106-132 DOI: http://dx.doi.org/10.46925//rdluz.34.08

organisations that have already implemented e-procurement save from 5\% to 20\% of purchasing costs (Ivanov \& Sevastianova, 2015). Also, the introduction of electronic procurement in the EU is widely supported by the International Monetary Fund, the European Central Bank and the European Commission.

In accordance with the international obligations of Ukraine, it is necessary to introduce to the national legislation the international standards that are already recognised by the world community as effective and appropriate, with a view to convergence of public procurement markets around the world and unification of their legal regulation. Currently, Ukraine is obliged to adapt the core elements of the EU directives relating to government procurement to domestic legislation during the transitional period specified in the Association Agreement (up to eight years, which is registered in the schedule of implementation of EU directives in effect). In this case, the reformation of government procurement system requires a comprehensive approach and should not be confined only to the adoption of certain special rules and making a significant amount of tactical changes to legislative acts.

Interestingly, the Association Agreement stipulates that Ukraine has to adapt national legislation according to the principles of Directives 2004/18/EU and 2004/17/EU, which have already become void, so the explanatory note to the Law of Ukraine on Government Procurement 2015 contains references to Directives EU/24/2014 and 2014/25/EU.

On May 14, 2018, the Ukraine - EU Association Committee, with the trade membership attendance, has decided to update Appendix XXI to the Association Agreement (EU-Ukraine, 2018), in order to take into account the "new" EU Directives on government procurement adopted in 2014, in particular (EC, 2017): the provisions of the Directive 2014/23/EU on the award of Concession Contracts Conclusion, Directive 2014/24/EU on public procurement and Directive 2014/25/EU on procurement by entities operating in the water, energy and transport sectors, and postal services sectors. In order to harmonize the thresholds of the EU and Ukraine commitments regarding the WTO GPA (WTO, 2020d) with the current definitions in EUR, they were also insignificantly increased (in particular: for government contracts of central state authorities - from EUR 133.000 up to EUR 135.000; in other cases - from EUR 206.000 up to EUR 209.000; for state concessions and contracts in the utility and infrastructure sectors - EUR 
REVISTA DE LA UNIVERSIDAD DEL ZULIA. 3é época. Año 12 N$^{\circ}$ 34, 2021 Viktoriia Holubieva et al. /// Public procurement in Ukraine in the context of international ... 106-132 DOI: http://dx.doi.org/10.46925//rdluz.34.08

5.150.000 - 5.225.000 (accordingly), etc.), and as for some positions, EUR 1.000.000 (in the utility and infrastructure sectors) was established (for example, for social and other specific service contracts - EUR 750.000 (state-based). Therefore, it is possible to predict the further updating and insignificant growth of thresholds in Appendix XXI to the Association Agreement of 2014. In this case, it should be noted that this adjustment was not made in Article 10:4 of the Law of Ukraine "On Public Procurement".

At the same time, it should be noted that within the GPA framework, in comparison with the Association Agreement, the list of types of government procurement is smaller (in particular, regarding procurement in the utilities sector, separate types of services and goods, state concessions).

Moreover, the fewer signatories of /parties to an international treaty are, the more specific its terms and conditions become. One can even speak about strengthening the "mandatory nature" of international acts while reducing the number of its participants, or the transition from the universal to the regional or bilateral international regulation of some or other types of relations.

In fact, the majority part of the WTO GPA and Association Agreement provisions in the field of government procurement has already been implemented or is being implemented by Ukraine. Indeed, taking into account the access to the EU market obtained within the GPA framework, Ukraine has already not so many external incentives for the full compliance with the obligations to harmonize the legislation under the Association Agreement than it was expected at its signing. One cannot forget that the enhancement of Ukraine's positions on the international stage contributes to performing its own international obligations, especially to the countries and international organizations / integrations, partners, donors and creditors.

\section{Conclusion}

Thus, it can be argued that the source systems for regulating the area of government/public procurement at the international level consist of: a) international multilateral (universal and regional) and bilateral contracts; b) decisions of international organizations (imperative and dispositive). And, at the national intrastate level, they consist of 
REVISTA DE LA UNIVERSIDAD DEL ZULIA. 3e época. Año $12 \mathrm{~N}^{\circ} 34,2021$ Viktoriia Holubieva et al. /// Public procurement in Ukraine in the context of international ... 106-132 DOI: http://dx.doi.org/10.46925//rdluz.34.08

(whole-of-government/ federal and regional): a) legislative (general and special /sectoral) acts; b) subordinate statutory instruments.

International legal regulation of public procurement does not refer to obligatory, widely used provisions of international law, it is applied in cases where the state gives consent to its application on its own, however, it should be admitted that there are the generally accepted regulations and provisions, observed by a vast majority of states. In turn, the number of states harmonising/adapting national legislation to the specific international legal standards of government procurement is quite small (a limited number of member states of the WTO Government Procurement Agreement (GPA), or the countries that have concluded generally bilateral international agreements, the provisions of which are fully or partially consider the regulation of public procurement). The most unified, practically implemented and "successful" regulation is the legal regulation in government procurement within the framework of the WTO and the EU. On the whole, government/public procurement is the scope of national legislation of each state, rather than of international organisations of regional economic integration. The institutional and legal coverage/regulation of government procurement in Ukraine is focused on reforming and building a system that would meet the standards of the EU and the WTO. The system of national legal regulation of government procurement of Ukraine is characterised by an extensive system of newly adapted acts, most of which are delegated legislation, regulating individual highly specialised issues, and the main the provisions are enshrined by On Public Procurement, Law of Ukraine, of Dec. 25, 2015, No.922-VIII.

The accession to international sectoral/special contracts in the field of government / public procurement (the WTO Agreement on Government Procurement 1994), or the inclusion of provisions/commitments on this issue in more general international agreements (the Association Agreement between Ukraine and the EU 2014), and the relevant harmonization/adaptation of the national legislation due to this fact are only one aspect (rather complex and long-term, but not determinative one). The development and introduction /reduction to practice (taking into account the OECD public procurement principles) of the effective mechanism for the implementation, management, control and supervision (including liability, punishment and encouragement) of the public procurement area in particular are a 


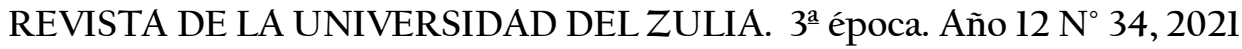
Viktoriia Holubieva et al. /// Public procurement in Ukraine in the context of international ... 106-132 DOI: http://dx.doi.org/10.46925//rdluz.34.08

completely different question that can undo all efforts of negotiable and rulemaking activities (at the international and national levels), as well as the "advanced" insights and experience. Ukraine cannot neglect, but, on the contrary, needs to use more actively the protective, organizational and legal instruments (international and national ones), on the one hand, for defending national economic interests and security, and on the other hand - for supporting and protecting interests of national commodity producers and commodity consumers on the market of government/public procurement.

\section{References}

European Commission (EC). (2014). Amending Directive 2014/24/EU of the European Parliament and of the Council in respect of the application thresholds for the procedures for the award of contracts, Commission Delegated Regulation (EU), No. 2017/2365, dated Dec. 18, 2017. https://eurlex.europa.eu/legal-content/EN/TXT/?uri=celex:32017R2365

EU-Ukraine. (2014). Association Agreement between the European Union, the European Atomic Energy Community and their member states on the one part, and Ukraine, on the other part.

EU-Ukraine. (2018). Resolution of the Ukraine - EU Association Committee with the trade membership attendance. Updating of Appendix XXI to Chapter 8 'Government Procurement`of Section IV 'Trade and Trade-Related Issues` of the Association Agreement and Positive Opinion on the Strategy for Reforming the Public Procurement System ('roadmap'), No. 1/2018, May 14.

EU-Ukraine. (2019). Integration within Association: dynamics of the EU - Ukraine Agreement Implementation. (Project 'Civic Synergy' of the International renaissance foundation. Kyiv, January 2019). 32-38.

Ivanov, A.V. \& Sevastianova, H.S. (2015). Line of reforming the government procurement system. Economic challenges. Economics and National Economy Management, 2: 65-70.

Ministry of Economic Development and Trade of Ukraine. (MEDTU). (2016). Order On Renaming the Zovnishtorgvydav Ukrainy State Enterprise and the Approval of the Articles of Association of the ProZorro State Enterprise, No. 1220, July 26.

OECD. (2009). OECD Principles for Integrity in Public Procurement.

Pokrovskaya, V.V. \& Uskova, Y.A. (2008). Modern foreign experience in the field of the government procurement development. Russian Foreign Economic Bulletin, 3: 32-38.

Prozorro Nd. Infobox. (n.d.). Center for Knowledge about Public Procurement. Online-courses at Prozorro. https://infobox.prozorro.org/courses

Shadrina, E.V. \& Romodina, I.V. (2017). Sustainable public procurement: international experience. Public Administration Issues, 1: 160-165.

UNCITRAL. (1995). The UNCITRAL Model Law 'On Procurement of Goods, Construction and Services` with the Guide to its Enactment. New York: UN. 
REVISTA DE LA UNIVERSIDAD DEL ZULIA. 3a época. Año $12 \mathrm{~N}^{\circ} 34,2021$ Viktoriia Holubieva et al. /// Public procurement in Ukraine in the context of international ... 106-132 DOI: http://dx.doi.org/10.46925//rdluz.34.08

Verkhovna Rada of Ukraine. (VRU). (2008). On the Ratification of the Protocol on the Accession of Ukraine to the World Trade Organisation, Law of Ukraine, No.250-VI, Apr. 10.

Verkhovna Rada of Ukraine (VRU). (2014). On the Ratification of the Association Agreement between the European Union, the European Atomic Energy Community and their Member States on the One Part, and Ukraine, on the Other Part, Law of Ukraine, No. 1678-VII, Sept. 16.

Verkhovna Rada of Ukraine. (VRU). (2015). On Public Procurement, Law of Ukraine, No. 922-VIII, Dec. 2.

Verkhovna Rada of Ukraine. (VRU). (2016). On the Accession of Ukraine to the Government Procurement Agreement, Law of Ukraine, No. 1029-VIII, Mar. 16.

WTO, Official website of WTO. (2016, July 29). Members and Observers. in About WTO. https://www.wto.org/english/thewto_e/whatis_e/tif_e/org6_e.htm

WTO. (1947). General Agreement on Tariffs and Trade, Oct. 30.

WTO. (1994a). Agreement Establishing the World Trade Organization, Apr. 15 (Marrakesh).

WTO. (1994b). Agreement on Government Procurement.

WTO. (1994c). Dispute Settlement Understanding.

WTO. (1994d). Trade Policy Review Mechanism.

WTO. (2008). Protocol on the Accession of Ukraine to the World Trade Organisation, Feb. 5, Geneva.

WTO. (2012). Protocol on Amendments to the WTO Government Procurement Agreement, Mar. 30 .

WTO. (2015). Resolution of the WTO Committee on Government Procurement. Accession of Ukraine to the Government Procurement Agreement, November 11 (WTO GPA/133 dd).

WTO. (2020a). What is the GPA? In Government Procurement. https://www.wto.org/english/tratop_e/gproc_e/gp_gpa_e.htm

WTO. (2020b). National Platforms for Public Procurement of WTO GPA Members. https://egpa.wto.org/en/Help/QuickAccess

WTO. (2020c). Disputes by Agreement. In Dispute Settlement. https://www.wto.org/english/tratop_e/dispu_e/dispu_agreements_index_e.htm?id=Al5

WTO. (2020d). National Platforms for Public Procurement of WTO GPA Members. https://egpa.wto.org/en/Agreement/Latest

Zakharova, O., Harasymiv, O., Sosnina, O., Soroka, O., \& Zaiets, I. (2021). Comparative legal analysis of the anti-corruption policy in Ukraine and Poland. Cuestiones Politicas, 39(69), 91-114. https://doi.org/10.46398/cuestpol.3969.05 